\title{
Six-Armed Structures Based on Benzene Ring, Synthesis and Characterization via Sonogashira Coupling
}

\author{
Mohammed Hadi Ali Al-Jumaili ${ }^{1,2, *}$, Ahmed Solaiman Hamed ${ }^{3}$, Nihat Akkurt ${ }^{4}$, and Lokman Torun ${ }^{5, * *}$ \\ ${ }^{1}$ Department of Chemistry, Faculty of Science and Arts, Yildiz Technical University, İstanbul, Turkey \\ ${ }^{2}$ College of Dentistry, Al Turath University College, Baghdad, Iraq \\ ${ }^{3}$ Department of Chemistry, College of Applied Science, University of Fallujah, Al-Anbar, Iraq \\ ${ }^{4}$ Department of Chemistry, Faculty of Science and Art, Kirklareli University, Kirklareli, Turkey \\ ${ }^{5}$ TORKIM ARGE, Inc., Yildiz Technical University, Technology Developing Zone, Incubation Center, 34220 Esenler, İstanbul, Turkey
}

\section{*Corresponding author:}

tel: $+90-536-2077645$

email: Mo2006h2000@yahoo.com; ltorun@yildiz.edu.tr**

Received: September 10, 2019

Accepted: October 31, 2019

DOI: $10.22146 /$ ijc.49419

\begin{abstract}
New six-armed compounds consist of benzene ring as a central core substituted with aromatic ring and three rod-like armed of 2-chloro-4,6-bis(dodecyloxy)1,3,5-triazine as the peripheral arms unit which were obtained by sequential nucleophilic substitution of chlorine atoms in cyanuric chloride. The substitution took place at the acetylenic periphery on the central benzene ring by cross-coupling. Equimolar mixtures of the six-armed compounds based on the benzene core with the complementary 4dodecyloxybenzoic acid, which already possessed liquid crystal property, resulting in the organic salt. The organic salts and structures were investigated by differential scanning calorimetry (DSC) and confirmed by spectroscopic methods $\left({ }^{1} \mathrm{H}-\mathrm{NMR},{ }^{13} \mathrm{C}-\mathrm{NMR}\right.$, Mass spectrometry, and FT-IR).
\end{abstract}

Keywords: triazine; liquid crystals; hydrogen bonding; benzene core derivatives; synthesis; characterization

\section{- INTRODUCTION}

Multi-arm liquid crystals exhibited very specific electro-optical phenomena and wide applications [1-2]. Chiral liquid crystalline materials use in flexible color display applications [3-5]. Branched-arm LCs have a higher molecular weight in comparing with the conventional low molecular mass compounds, which usually contain a core and a few mesogenic units as the side arm; that is why it attracted much attention for their special molecular structures and interesting properties. Derivatives of benzene [6-8], condensed aromatic rings [9], are often used as cores of the multi-arm compounds. The multi-arm liquid crystal shows different properties such as lower melting temperature, lower viscosity, good solubility, etc., from the linear dimers, trimers, and oligomers [10-12]. One of the most interested classes in the liquid crystal is the star-shaped, which has been paid much attention in recent years [13-16].
Heterocycles are important in the design and synthesis of organic functional materials, especially in the development of thermotropic liquid crystals, since phase structure, polarity, geometry, luminescence, and many other molecular properties can be varied by the introduction of heteroatoms [17-20]. In recent years, much interest focus on the synthesis and characterization of compounds containing a 1,3,5triazine unit or used as a central core due to their interesting properties, such as liquid crystalline and nonlinear optical properties as well as their applications in other fields [21-24]. The 1,3,5-triazine is an electronaccepting unit, which can be substituted at the 2,4,6positions with an appropriate aromatic rigid core through linking groups at the side arms to give a $\mathrm{C}_{3}$ symmetrical system (star-shaped) that is able to form columnar mesophases [25]. Moreover, the extension of the electronic conjugation of these types of mesogens 
should give CLCs with luminescent properties and high charge-carrier mobility [26-27].

Supramolecular liquid crystals (LCs), obtained via intermolecular hydrogen bonding have attracted considerable attention due to their ability of existence of the mesophase. In these cases, the hydrogen bonded complexes are formed between two identical molecules, and the system can be considered as self-complementary [28].

In this study, our research focuses on star-shaped molecules bearing three aromatic arms and three rod-like armed of 2-chloro-4,6-bis(dodecyloxy)-1,3,5-triazine as the peripheral arms unit linking through triple bond on the benzene core, started from 1,3,5-trichloro-2,4,6triiodobenzene, which is derived from 1,3,5trichlorobenzene and 2-chloro-4,6-bis(dodecyloxy)-1,3,5triazine which is derived from 2,4,6-trichloro-1,3,5triazine. The synthesis of organic salts was obtained via intermolecular hydrogen bonding between six-armed compounds and 4-dodecyloxybenzoic acid, which is already possessed liquid crystal property to increase the possibility of liquid crystalline of the mixture [29].

\section{- EXPERIMENTAL SECTION}

\section{Materials}

The reagents and solvents used were obtained from Merck with pro analysis grade without further purification, i.e., cyanuric chloride, dodecan-1-ol, ethynylbenzene, 1,3,5-trichlorobenzene, 2-iodo-thiophene, 2-ethynyl benzene, ethynyltrimethylsilane, copper iodide, potassium carbonate, tetrakis (triphenylphosphine)palladium and triethylamine, tetrahydrofuran, dimethylformamide, and dioxane. Thin-layer chromatography was performed using aluminum plates $(20 \times 20 \mathrm{~cm})$ coated with silica gel 60 F254 (Merck), while column chromatography was carried out using silica gel $60(0.063-0.200 \mathrm{~mm})$ from Merck.

\section{Instrumentation}

Structure elucidation of compounds was carried out using HRMS (High resolution mass spectrometry), FT-IR (Shimadzu Prestige-21, KBr discs), ${ }^{1} \mathrm{H}-\mathrm{NMR}(500 \mathrm{MHz})$ and ${ }^{13} \mathrm{C}-\mathrm{NMR}(125 \mathrm{MHz})\left(\mathrm{CDCl}_{3}\right.$, standard internal TMS) spectrometers. Liquid crystalline evaluation of the organic salts was performed using DSC (Differential scanning calorimetry).

\section{Procedure of Six-armed Compounds}

\section{2-chloro-4,6-bis(dodecyloxy)-1,3,5-triazine (2)}

A mixture of 2,4,6-trichloro-1,3,5-triazine (1) (1.90 g, $10.3 \mathrm{mmol})$, dodecan-1-ol (3.84 g, $20.6 \mathrm{mmol})$ and $\mathrm{K}_{2} \mathrm{CO}_{3}(2.84 \mathrm{~g}, 20.6 \mathrm{mmol})$ were dissolved in $10.0 \mathrm{~mL}$ of THF (Scheme 2). The mixture was stirred at $50{ }^{\circ} \mathrm{C}$ for $5 \mathrm{~h}$ under argon atmosphere. The solution was poured into a mixture of ethyl acetate $(20.0 \mathrm{~mL})$ and water $(20.0 \mathrm{~mL})$. The organic layer after separation was dried with sodium sulfate. Under vacuum, the solvent was evaporated and the crude product was purified by column chromatography with hexane/ethyl acetate ( $5 \% \mathrm{EtOAc}$ ) as an eluent to give white solid materials with a yield (3.50 g, 70\%). ${ }^{1} \mathrm{H}-\mathrm{NMR}$ $\left(500 \mathrm{MHz}, \mathrm{CDCl}_{3}\right) \delta 3.70\left(\mathrm{t}, J=6.7 \mathrm{~Hz}, 4 \mathrm{H}, \mathrm{OCH}_{2}\right), 1.81-$ $1.51\left(\mathrm{~m}, 4 \mathrm{H}, \mathrm{CH}_{2}\right), 1.58-1.20\left(\mathrm{~m}, 36 \mathrm{H}, \mathrm{CH}_{2}\right), 0.94(\mathrm{t}, J=$ $\left.6.9 \mathrm{~Hz}, 6 \mathrm{H}, \mathrm{CH}_{3}\right){ }^{13} \mathrm{C}-\mathrm{NMR}\left(126 \mathrm{MHz}, \mathrm{CDCl}_{3}\right) \delta 173.17$ (O-C $\left.\mathrm{C}_{\text {het }}\right), 172.18$ (Cl-C $\left.\mathrm{C}_{\text {het }}\right), 68.54\left(\mathrm{OCH}_{2}\right), 31.95,29.68$, $29.66,29.61,29.56,29.38,29.33,28.68,25.86,22.72,14.14)$. HRMS $=\mathrm{m} / \mathrm{z} \mathrm{M}{ }^{+}$and $[\mathrm{M}+\mathrm{K}]^{+}$calcd for $\mathrm{C}_{27} \mathrm{H}_{50} \mathrm{ClN}_{3} \mathrm{O}_{2}$ : 483.36; found: $483.35,523.3282$ respectively.

\section{2,4-bis(dodecyloxy)-6-((trimethylsilyl)ethynyl)-1,3,5- triazine (3)}

A mixture of 2-chloro-4,6-bis(dodecyloxy)-1,3,5triazine (2) (1.20 g, $2.47 \mathrm{mmol}$ ), $\mathrm{K}_{2} \mathrm{CO}_{3}(0.40 \mathrm{~g}, 22.0$ $\mathrm{mmol})$, ethynyltrimethylsilane $(0.29 \mathrm{~g}, 2.96 \mathrm{mmol})$, $\mathrm{Pd}\left(\mathrm{Pph}_{3}\right)_{4}(0.28 \mathrm{~g}, 0.24 \mathrm{mmol})$, $\mathrm{CuI}(0.09 \mathrm{~g}, 0.49 \mathrm{mmol})$, were dissolved in $10.0 \mathrm{~mL}$ of THF (Scheme 2). The mixture was refluxed for $6 \mathrm{~h}$ under argon atmosphere. The solution was poured into a mixture of ethyl acetate $(20.0 \mathrm{~mL})$ and water $(20.0 \mathrm{~mL})$. The organic layer after separation was dried with sodium sulfate. Under vacuum, the solvent was evaporated to give brown oily material with a yield $(1.10 \mathrm{~g}, 81 \%) . \mathrm{HRMS}=\mathrm{m} / \mathrm{z}[\mathrm{M}+\mathrm{H}]^{+}$ calcd for $\mathrm{C}_{32} \mathrm{H}_{59} \mathrm{~N}_{3} \mathrm{O}_{2} \mathrm{Si}$ : 545.44; found: 546.39 .

\section{Trimethyl(thiophen-2-ylethynyl) silane (5)}

A mixture of 2-iodothiophene (4) (0.40 g, 1.90 $\mathrm{mmol}), \mathrm{K}_{2} \mathrm{CO}_{3}$ (0.394 g, $\left.2.85 \mathrm{mmol}\right), 2$-methylbut-3-yn2-ol (0.17 g, $2.09 \mathrm{mmol}), \mathrm{Pd}\left(\mathrm{Pph}_{3}\right)_{4}(0.021 \mathrm{~g}, 0.019 \mathrm{mmol})$, $\mathrm{CuI}(0.007 \mathrm{~g}, 0.038 \mathrm{mmol})$, were dissolved in $10.0 \mathrm{~mL}$ of 
THF under argon atmosphere (Scheme 2). The mixture was refluxed for $6 \mathrm{~h}$. The solution was poured into a mixture of ethyl acetate $(20.0 \mathrm{~mL})$ and water $(20.0 \mathrm{~mL})$. The organic layer after separation was dried with sodium sulfate. Under vacuum, the solvent was evaporated to give brown oily material with a yield $(0.27 \mathrm{~g}, 87 \%)$. HRMS = $\mathrm{m} / \mathrm{z}[\mathrm{M}+\mathrm{H}]^{+}$calcd for $\mathrm{C}_{9} \mathrm{H}_{10} \mathrm{OS}$ : 166.0; found: 167.05.

\section{2-ethynylthiophene (6)}

A mixture of trimethyl(thiophen-2-ylethynyl) silane (5) $(0.25 \mathrm{~g}, 1.38 \mathrm{mmol})$ and $\mathrm{K}_{2} \mathrm{CO}_{3}(0.249 \mathrm{~g}, 1.80 \mathrm{mmol})$ were dissolved in $10.0 \mathrm{~mL}$ of toluene (Scheme 2). The mixture was stirred for $12 \mathrm{~h}$ at $80^{\circ} \mathrm{C}$. The solution was poured into a mixture of dichloromethane $(20.0 \mathrm{~mL})$ and water $(20.0 \mathrm{~mL})$. The organic layer after separation was dried with sodium sulfate. Under vacuum, the solvent was evaporated to give brown oily material with a yield $(0.1 \mathrm{~g}$, 83\%). HRMS $=\mathrm{m} / \mathrm{z}\left[2 \mathrm{M}^{+}\right]$calcd for $\mathrm{C}_{6} \mathrm{H}_{4} \mathrm{~S}: 108$; found: 108 .

\section{1,3,5-trichloro-2,4,6-triiodobenzene (8)}

Periodic acid ( $3.00 \mathrm{~g}, 13.2 \mathrm{mmol}$ ) was added slowly to $50.0 \mathrm{~mL}$ of concentrated sulfuric acid and stirred for $1 \mathrm{~h}$ then Potassium iodide ( $6.50 \mathrm{~g}, 39.5 \mathrm{mmol}$ ) was added to the mixture slowly at $0{ }^{\circ} \mathrm{C}$, after the reaction reached room temperature, 1,3,5-trichlorobenzene (7) (0.789 g, 4.38 $\mathrm{mmol}$ ) was added (Scheme 3 ). The solution was poured into a mixture of ethyl acetate $(50.0 \mathrm{~mL})$ and water $(50.0 \mathrm{~mL})$. The organic layer after separation was dried with sodium sulfate. Under vacuum, the solvent was evaporated to give light yellow solid materials with a yield (1.50 g, 62\%), MP. $280{ }^{\circ} \mathrm{C}$. HRMS $=\mathrm{m} / \mathrm{z} \mathrm{M}^{+}$and $[\mathrm{M}+\mathrm{H}]^{+}$calcd for $\mathrm{C}_{6} \mathrm{Cl}_{3} \mathrm{I}_{3}$ : 557.6; found: 558.6 .

\section{((2,4,6-trichlorobenzene-1,3,5-triyl) tris(ethyne-2,1-diyl)) tribenzene (9a)}

A mixture of 1,3,5-trichloro-2,4,6-triiodobenzene (8) $(0.50 \mathrm{~g}, 0.90 \mathrm{mmol})$, ethynylbenzene $(0.28 \mathrm{~g}, 2.68 \mathrm{mmol})$, $\mathrm{Pd}\left(\mathrm{Pph}_{3}\right)_{4}(0.01 \mathrm{~g}, 0.09 \mathrm{mmol}), \mathrm{CuI}(0.03 \mathrm{~g}, 0.18 \mathrm{mmol})$ and $\mathrm{K}_{2} \mathrm{CO}_{3}(0.28 \mathrm{~g}, 2.86 \mathrm{mmol})$ were dissolved in $10.0 \mathrm{~mL}$ of dioxane (Scheme 3). The mixture was stirred at $75^{\circ} \mathrm{C}$ for $6 \mathrm{~h}$ under argon atmosphere. The solution was poured into a mixture of ethyl acetate $(20.0 \mathrm{~mL})$ and water $(20.0 \mathrm{~mL})$. The organic layer after separation was dried with sodium sulfate. Under vacuum, the solvent was evaporated and the crude product was purified by column chromatography with hexane/ethyl acetate ( $5 \% \mathrm{EtOAc})$ as an eluent to give white powder with a yield $(0.35 \mathrm{~g}, 81 \%)$. MP. $140-145^{\circ} \mathrm{C}$. ${ }^{1} \mathrm{H}-\mathrm{NMR}\left(500 \mathrm{MHz}, \mathrm{CDCl}_{3}\right)(7.6(\mathrm{~m}, 1 \mathrm{H}), 7.4(\mathrm{~m}, 2 \mathrm{H})$. ${ }^{13} \mathrm{C}-\mathrm{NMR}(142,132.5,129.2,128.5,121.8,81.6,74)$. HRMS $=\mathrm{m} / \mathrm{z}[\mathrm{M}+\mathrm{H}]^{+}$calcd for $\mathrm{C}_{30} \mathrm{H}_{15} \mathrm{Cl}_{3}: 481.80$; found: 483.02 .

\section{2,2',2"-((2,4,6-trichlorobenzene-1,3,5-triyl) tris (ethyne- 2,1diyl)) trithiophene (9b)}

A mixture of 1,3,5-trichloro-2,4,6-triiodobenzene (8) (0.50 g, $0.89 \mathrm{mmol}), 2$-ethynylthiophene (6) (0.48 g, $2.69 \mathrm{mmol}), \mathrm{Pd}\left(\mathrm{Pph}_{3}\right)_{4}(0.10 \mathrm{~g}, 0.089 \mathrm{mmol}), \mathrm{CuI}(0.03 \mathrm{~g}$, $0.178 \mathrm{mmol})$ and $\mathrm{K}_{2} \mathrm{CO}_{3}(0.39 \mathrm{~g}, 2.84 \mathrm{mmol})$ were dissolved in $10.0 \mathrm{~mL}$ of dioxane (Scheme 3). The mixture was stirred at $75^{\circ} \mathrm{C}$ for $6 \mathrm{~h}$ under argon atmosphere. The solution was poured into a mixture of ethyl acetate $(20.0 \mathrm{~mL})$ and water $(20.0 \mathrm{~mL})$. The organic layer after separation was dried with sodium sulfate. Under vacuum, the solvent was evaporated and the crude product was purified by column chromatography with hexane/ethyl acetate (5\% EtOAc) as an eluent to give pale yellow powder with a yield (0.37 g, 84\%), MP.124-127 ${ }^{\circ} \mathrm{C} .{ }^{1} \mathrm{H}-\mathrm{NMR}:\left(\mathrm{CDCl}_{3}\right)$ $(7.3(\mathrm{~m}, 1 \mathrm{H}) 3 \times(1 \mathrm{H}), 7.17(\mathrm{~m}, 1 \mathrm{H}) 3 \times(1 \mathrm{H}), 6.7(\mathrm{dt}, J=$ 6.8, $3.4 \mathrm{~Hz}, 1 \mathrm{H}) 3 \times(1 \mathrm{H})),{ }^{13} \mathrm{C}-\mathrm{NMR}:(146,141,138,132$, $131,129,100,98)$. HRMS $=\mathrm{m} / \mathrm{z} \mathrm{M}^{+}$and $[\mathrm{M}+\mathrm{H}]^{+}$calcd for $\mathrm{C}_{24} \mathrm{H}_{9} \mathrm{Cl}_{3} \mathrm{~S}_{3}$ : 499.88; found: 499.89 and 500.88, respectively.

6,6',6"-((2,4,6-tris(phenylethynyl)benzene-1,3,5-triyl) tris(ethyne-2,1-diyl)) tris(2,4-bis(dodecyloxy)-1,3,5triazine) (10a)

((2,4,6-trichlorobenzene-1,3,5-triyl)tris(ethyne-2,1diyl))tribenzene (9a) (0.15 g, $0.31 \mathrm{mmol}), 2,4$-bis(dodecy loxy)-6-((trimethylsilyl)ethynyl)-1,3,5-triazine (3) (0.51 g, $0.93 \mathrm{mmol}), \mathrm{Pd}\left(\mathrm{Pph}_{3}\right)_{4}(0.035 \mathrm{~g}, 0.031 \mathrm{mmol}), \mathrm{CuI}(0.011 \mathrm{~g}$, $0.06 \mathrm{mmol})$ and $\mathrm{K}_{2} \mathrm{CO}_{3}(0.136 \mathrm{~g}, 0.99 \mathrm{mmol})$ were dissolved in $10.0 \mathrm{~mL}$ of dioxane (Scheme 3). The mixture was stirred at $80{ }^{\circ} \mathrm{C}$ for $16 \mathrm{~h}$ under argon atmosphere. The organic layer after separation was dried with sodium sulfate. Under vacuum, the solvent was evaporated and the crude product was purified by column chromatography with hexane/ethyl acetate (5\% EtOAc) as an eluent to obtain light brown with a yield $(0.42 \mathrm{~g}, 75 \%) .{ }^{1} \mathrm{H}-\mathrm{NMR}$ : $\left(\mathrm{CDCl}_{3}\right)(7.3(\mathrm{dt}, J=11.1,5.4 \mathrm{~Hz}, 6 \mathrm{H}), 7.18(\mathrm{~m}, 9 \mathrm{H}), 4.15$ ( $\left.\mathrm{t}, J=6.8 \mathrm{~Hz}, 12 \mathrm{H}, \mathrm{OCH}_{2}\right), 1.64-1.50\left(\mathrm{~m}, 12 \mathrm{H}, \mathrm{CH}_{2}\right)$, $1.44-1.1\left(\mathrm{~m}, 108 \mathrm{H}, \mathrm{CH}_{2}\right), 0.7\left(\mathrm{t}, J=6.8 \mathrm{~Hz}, 18 \mathrm{H}, \mathrm{CH}_{3}\right) .{ }^{13} \mathrm{C}-$ NMR: $(173,171,142,139,132,129,128,122,108,98,81$, 
$74,68,32,31,30,29,28,24,22,12) . \mathrm{MS}=\mathrm{m} / \mathrm{z}[\mathrm{M}+2]^{+}$calcd for $\mathrm{C}_{117} \mathrm{H}_{165} \mathrm{~N}_{9} \mathrm{O}_{6}$ : 1793.6 ; found: $896.64 \times 2=1793.28$.

\section{6,6',6"--((2,4,6-tris(thiophen-2-ylethynyl) benzene-1,3,5- triyl) tris(ethyne-2,1-diyl)) tris(2,4-bis(dodecyloxy)-1,3,5- triazine) (10b)}

2,2',2"-((2,4,6-trichlorobenzene-1,3,5-triyl)tris(ethyne -2,1-diyl))trithiophene (9b) (0.15 g, $0.3 \mathrm{mmol}), 2,4$ bis(dodecyloxy)-6-((trimethylsilyl)ethynyl)-1,3,5-triazine (3) $(0.49 \mathrm{~g}, 0.90 \mathrm{mmol}), \mathrm{Pd}\left(\mathrm{Pph}_{3}\right)_{4}(0.034 \mathrm{~g}, 0.03 \mathrm{mmol})$, $\mathrm{CuI}(0.011 \mathrm{~g}, 0.06 \mathrm{mmol})$ and $\mathrm{K}_{2} \mathrm{CO}_{3}(0.13 \mathrm{~g}, 0.96 \mathrm{mmol})$ were dissolved in $10.0 \mathrm{~mL}$ of dioxane (Scheme 3). The mixture was stirred at $80{ }^{\circ} \mathrm{C}$ for $16 \mathrm{~h}$ under argon atmosphere. The solution was poured into a mixture of ethyl acetate $(20.0 \mathrm{~mL})$ and water $(20.0 \mathrm{~mL})$. The organic layer after separation was dried with sodium sulfate. Under vacuum, the solvent was evaporated and the crude product was purified by column chromatography with hexane/ethyl acetate (5\% EtOAc) as an eluent to obtain light brown with a yield (0.41g, 76\%). ${ }^{1} \mathrm{H}-\mathrm{NMR}$ : $\left(\mathrm{CDCl}_{3}\right)$ $\left(7.25(\mathrm{~m}, 6 \mathrm{H}), 6.95(\mathrm{~d}, 3 \mathrm{H}), 4.3\left(\mathrm{t}, J=6.8 \mathrm{~Hz}, 12 \mathrm{H}, \mathrm{OCH}_{2}\right)\right.$, $1.6\left(\mathrm{~m}, 12 \mathrm{H}, \mathrm{CH}_{2}\right), 1.4-1.1\left(\mathrm{~m}, 108 \mathrm{H}, \mathrm{CH}_{2}\right), 0.8(\mathrm{t}, J=6.8$ $\left.\mathrm{Hz}, 18 \mathrm{H}, \mathrm{CH}_{3}\right) .{ }^{13} \mathrm{C}-\mathrm{NMR}:(173,166,162,134,131,128$, $127,121,114,98,87,68.5,32,31,30,29,28,24,22,12)$. HRMS $=\mathrm{m} / \mathrm{z}[\mathrm{M}+2 \mathrm{H}]^{+2}$ calcd for $\mathrm{C}_{111} \mathrm{H}_{159} \mathrm{~N}_{9} \mathrm{O}_{6} \mathrm{~S}_{3}: 1811.7$; found: $(906.58 \times 2-2=1811.16)$.

Second route of synthesis compounds 10(a-b): $6,6,6^{\prime \prime}$ ((2,4,6-trichlorobenzene-1,3,5-triyl) tris(ethyne-2,1-diyl)) tris(2,4-bis(dodecyloxy)-1,3,5-triazine) (11)

1,3,5-trichloro-2,4,6-triiodobenzene (8) ( $0.50 \mathrm{~g}, 0.89$ mmol), 2,4-bis(dodecyloxy)-6-((trimethylsilyl)ethynyl)1,3,5-triazine (3) (1.47 g, $2.69 \mathrm{mmol}), \mathrm{K}_{2} \mathrm{CO}_{3}(0.39 \mathrm{~g}, 2.84$ $\mathrm{mmol}), \mathrm{Pd}\left(\mathrm{Pph}_{3}\right)_{4}(0.01 \mathrm{~g}, 0.089 \mathrm{mmol}), \mathrm{CuI}(0.033 \mathrm{~g}$, $0.178 \mathrm{mmol}$ ), were dissolved in $10.0 \mathrm{~mL}$ of dioxane under argon atmosphere (Scheme 4). The mixture was stirred at $70{ }^{\circ} \mathrm{C}$ for $12 \mathrm{~h}$. The solution was poured into a mixture of ethyl acetate $(20.0 \mathrm{~mL})$ and water $(20.0 \mathrm{~mL})$. The organic layer was washed and dried over sodium sulphate. The solvent was removed under vacuum to give yellow solid material with yield $(1.10 \mathrm{~g}, 76 \%) .{ }^{1} \mathrm{H}-\mathrm{NMR}:\left(\mathrm{CDCl}_{3}\right)(4.3$ (t, $\left.12 \mathrm{H}, \mathrm{OCH}_{2}\right), 1.65\left(\mathrm{~m}, 4 \mathrm{H}, \mathrm{CH}_{2}\right), 1.35\left(\mathrm{~m}, 18 \mathrm{H}, \mathrm{CH}_{2}\right)$, 0.95 (t, 6H, $\left.\left.\mathrm{CH}_{3}\right)\right) .{ }^{13} \mathrm{C}-\mathrm{NMR}(173.5,171.3,145.6,126$. $100.3,97.89,68.5,31.9,29.65,29.6,29.5,29.3,28.6,25.8$, $22.7,14.1) . \mathrm{HRMS}=\mathrm{m} / \mathrm{z}[\mathrm{M}+2]$ and $\left[\mathrm{M}+2\left(\mathrm{NH}_{4}\right)\right]^{+2} \mathrm{calcd}$ for $\mathrm{C}_{93} \mathrm{H}_{150} \mathrm{Cl}_{3} \mathrm{~N}_{9} \mathrm{O}_{6}: 1594.1$; found: $797.52(797.52 \times 2=$ $1595.04), 816.09(816.09 \times 2-36=1596.1)$ respectively.

\section{4-(dodecyloxy) benzoic acid (4-DBA) (12)}

A solution of 4-hydroxy benzoic acid $(8.20 \mathrm{mmol})$, 1-bromododecane $(5.50 \mathrm{~mL}, 23.0 \mathrm{mmol}, 2.8 \mathrm{eq})$ and $\mathrm{KOH}(1.30 \mathrm{~g}, 23.0 \mathrm{mmol}, 2.8 \mathrm{eq})$ in ethanol $(25.0 \mathrm{~mL})$ was heated under reflux for 2 days (Scheme 5). By adding $10 \%$ aqueous $\mathrm{KOH}(25.0 \mathrm{~mL})$ to the mixture and refluxed overnight, the hydrolysis was carried out. After cooling down, the reaction mixture was acidified with $\mathrm{HCl}(6.0$ $\mathrm{M})$, the precipitate was filtered, washed with water and recrystallized from ethanol to obtain the pure product 4dodecyloxybenzoic acid, a white solid material with yield (4.55 g, 91\%). ${ }^{1} \mathrm{H}-\mathrm{NMR}\left(500 \mathrm{MHz}, \mathrm{CDCl}_{3}\right)$ showed peaks at $(\delta 8.10(\mathrm{~d}, 2 \mathrm{H}), 6.98(\mathrm{~d}, 2 \mathrm{H}), 4.07(\mathrm{t}, 2 \mathrm{H}), 1.84(\mathrm{~m}, 2 \mathrm{H})$, $1.48(\mathrm{~m}, 2 \mathrm{H}), 1.37-1.28(\mathrm{~m}, 16 \mathrm{H}), 0.91(\mathrm{t}, 3 \mathrm{H})$. The FTIR $(2914,2848,2559,1670,1604) \mathrm{cm}^{-1}$.

\section{Synthesis of organic salt}

4-DBA mesogenic unit (12) with a carboxyl group was added into a solution of compound $\mathbf{1 0}(\mathbf{a}-\mathbf{b})$ in $10 \mathrm{~mL}$ of dry THF with one to one ratio (Scheme 5). The resulting solution was sonicated for 15 min until a transparent solution was observed. Then, the solvent was removed in vacuum.

The organic salt (13a). ${ }^{1} \mathrm{H}-\mathrm{NMR}(7.9(\mathrm{~d}, 2 \mathrm{H}), 7.4(\mathrm{~d}$, $2 \mathrm{H}), 7.15(\mathrm{~m}, 3 \mathrm{H}), 6.8(\mathrm{~d}, 2 \mathrm{H}), 4.2\left(\mathrm{t}, 12 \mathrm{H}, \mathrm{OCH}_{2}\right), 3.85$ $\left(\mathrm{t},\left(\mathrm{OCH}_{2}\right), 1.75\left(\mathrm{~m}, 12 \mathrm{H}, \mathrm{CH}_{2}\right), 1.15\left(\mathrm{~m}, 108 \mathrm{H}, \mathrm{CH}_{2}\right), 0.7\right.$ $\left(\mathrm{t}, J=7.0 \mathrm{~Hz}, 18 \mathrm{H}, \mathrm{CH}_{3}\right)$. FT-IR $(2917,2855,2564,1694$, $1609,1560,1477,1419,1332,1274) . M S=\mathrm{m} / \mathrm{z}$ $[\mathrm{M}+3(\mathrm{HCOO})]^{-3}$ calcd for $\mathrm{C}_{136} \mathrm{H}_{195} \mathrm{~N}_{9} \mathrm{~N}_{9} \mathrm{O}_{9}$ : 2098.5; found: $744.496(744.496 \times 3-3 \times 45=2098.48)$.

The organic salt (13b). ${ }^{1} \mathrm{H}-\mathrm{NMR}(7.85(\mathrm{~d}, 2 \mathrm{H}), 7.25$ $(\mathrm{m}, 2 \mathrm{H}), 6.95(\mathrm{~d}, 1 \mathrm{H}), 6.75(\mathrm{~d}, 2 \mathrm{H}), 4.26\left(\mathrm{t}, 12 \mathrm{H}, \mathrm{OCH}_{2}\right)$, $3.8\left(\mathrm{t},\left(\mathrm{OCH}_{2}\right), 1.75\left(\mathrm{~m}, 12 \mathrm{H}, \mathrm{CH}_{2}\right), 1.3-1.15(\mathrm{~m}, 108 \mathrm{H}\right.$, $\left.\mathrm{CH}_{2}\right), 0.75\left(\mathrm{t}, 18 \mathrm{H}, \mathrm{CH}_{3}\right)$. FT-IR $(2915,2844,1680,1584$, $1530,1560,1490,1419,1278,1156)$.

\section{- RESULTS AND DISCUSSION}

In this contribution, six arms structures based on benzene ring were synthesized via Sonogashira-reaction using different substituted started with 1,3,5trichlorobenzene and 2,4,6-trichloro-1,3,5-triazine as described in (Scheme 1-5). The structures were confirmed 
<smiles>Clc1c(I)c(Cl)c(I)c(Cl)c1I</smiles>

$$
\begin{aligned}
& \text { 7a: } R_{1}=\text { P Ph hiopirene, } R_{2}=3 \\
& \text { 7b: } R_{1}=3
\end{aligned}
$$<smiles>[3H]C#CC</smiles><smiles>[R]C#Cc1c(Cl)c(C#C[R])c(Cl)c(C#C[R])c1Cl</smiles>

Scheme 1. Synthesis route of six arms compounds<smiles>Clc1nc(Cl)nc(Cl)n1</smiles>

1<smiles>CC#CCCCCCCCCC</smiles>

2<smiles>CCCOc1nc(C#C[SiH2]C)nc(OCC)n1</smiles>

3

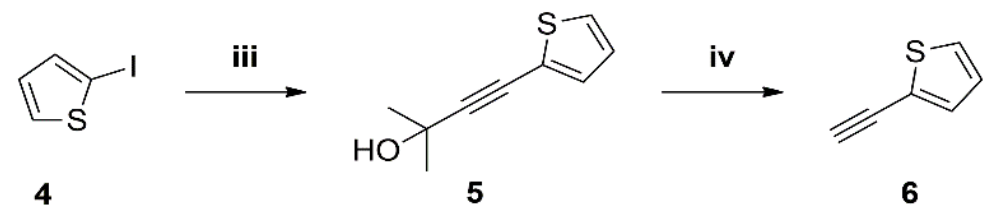

Scheme 2. Synthesis route of intermediate compounds. Reaction and condition: i) $\mathrm{K}_{2} \mathrm{CO}_{3}$, dodecan-1-ol, 0-50 ${ }^{\circ} \mathrm{C}, 5 \mathrm{~h}$, THF, ii) Ethynyltrimethylsilane, $\mathrm{K}_{2} \mathrm{CO}_{3}, \mathrm{Pd}\left(\mathrm{PPh}_{3}\right)_{4}, \mathrm{CuI}$, THF, Reflux, iii) 2-methylbut-3-yn-2-ol, $\mathrm{Pd}\left(\mathrm{PPh}_{3}\right)_{4}, \mathrm{CuI}$, $\mathrm{K}_{2} \mathrm{CO}_{3}$, THF, Reflux, iv) $\mathrm{K}_{2} \mathrm{CO}_{3}$, toluene, $80^{\circ} \mathrm{C}, 12 \mathrm{~h}$<smiles>CC(C)C</smiles>

7<smiles>Clc1c(I)c(Cl)c(I)c(Cl)c1I</smiles>

8<smiles>[R]C(C)C</smiles><smiles>[R]c1c(Cl)c([R])c(Cl)c([R])c1Cl</smiles>

9(a-b)

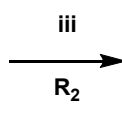<smiles>[R]Cc1c([R])c([R])c([R])c([R])c1[R]</smiles>

10(a-b)<smiles>[R]O[Na]</smiles>

Scheme 3. Synthesis route of six arms on the benzene ring. Reaction and condition: i) $\mathrm{H}_{5} \mathrm{IO}_{6}, \mathrm{H}_{2} \mathrm{SO}_{4}, \mathrm{KI}, 0{ }^{\circ} \mathrm{C} 10.0$ min, r.t., ii) $\mathrm{Pd}\left(\mathrm{PPh}_{3}\right)_{4}, \mathrm{CuI}, \mathrm{Et}_{3} \mathrm{~N}$ (3.2 eq), Dioxane, $75^{\circ} \mathrm{C}, 6 \mathrm{~h}$, iii) $\mathrm{Pd}\left(\mathrm{PPh}_{3}\right)_{4}, \mathrm{CuI}, \mathrm{K}_{2} \mathrm{CO}_{3}$, Dioxane, $80^{\circ} \mathrm{C}, 12 \mathrm{~h}$ 


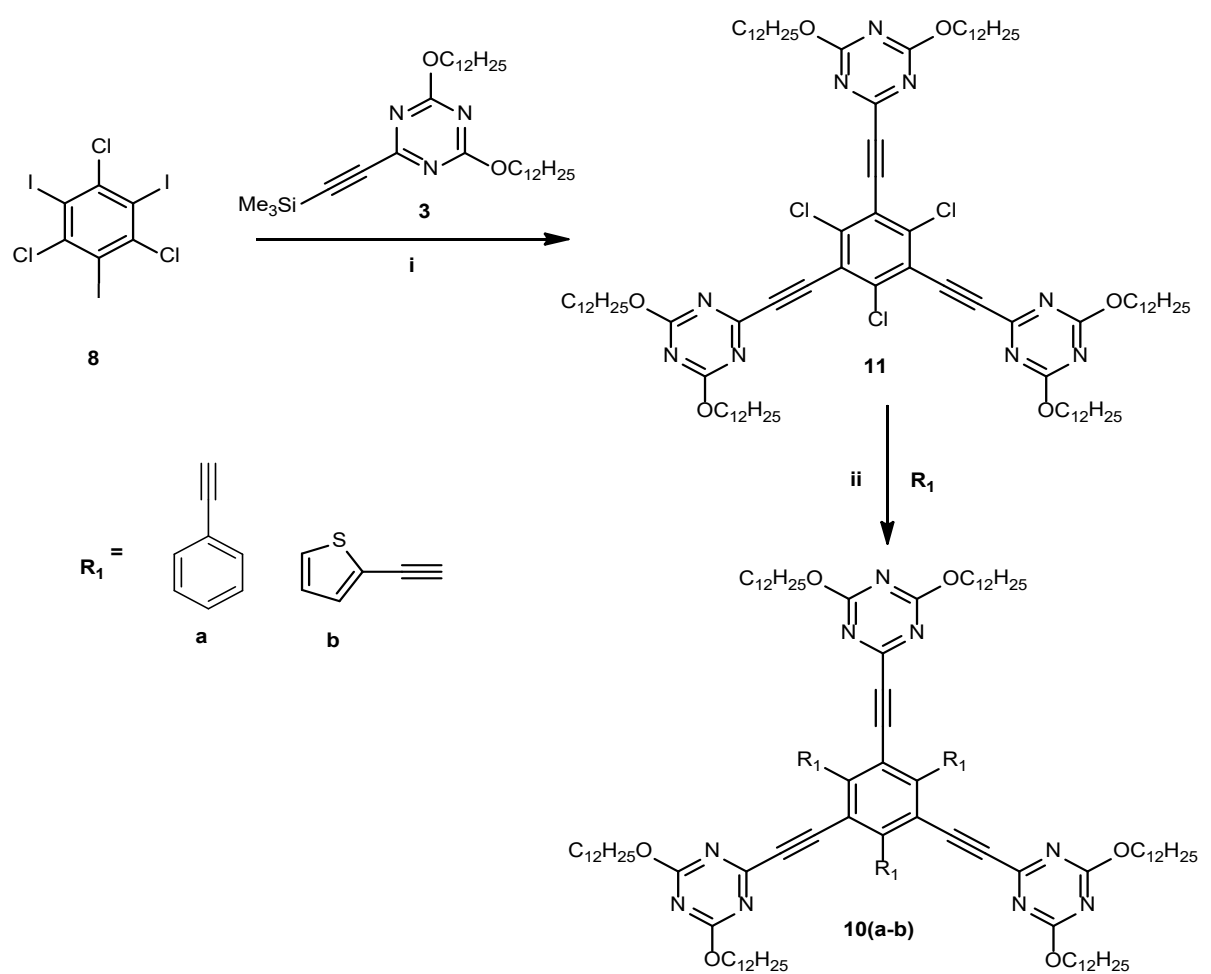

Scheme 4. Synthesis route of six arms compounds $10(\mathbf{a}-\mathbf{b})$. Reaction and condition: i) $\mathrm{Pd}\left(\mathrm{PPh}_{3}\right)_{4}, \mathrm{CuI}_{2} \mathrm{~K}_{2} \mathrm{CO}_{3}$, Dioxane, $70{ }^{\circ} \mathrm{C}, 6 \mathrm{~h}$, ii) $\mathrm{Pd}\left(\mathrm{PPh}_{3}\right)_{4}, \mathrm{CuI}, \mathrm{K}_{2} \mathrm{CO}_{3}$, Dioxane, $80{ }^{\circ} \mathrm{C}, 12 \mathrm{~h}$

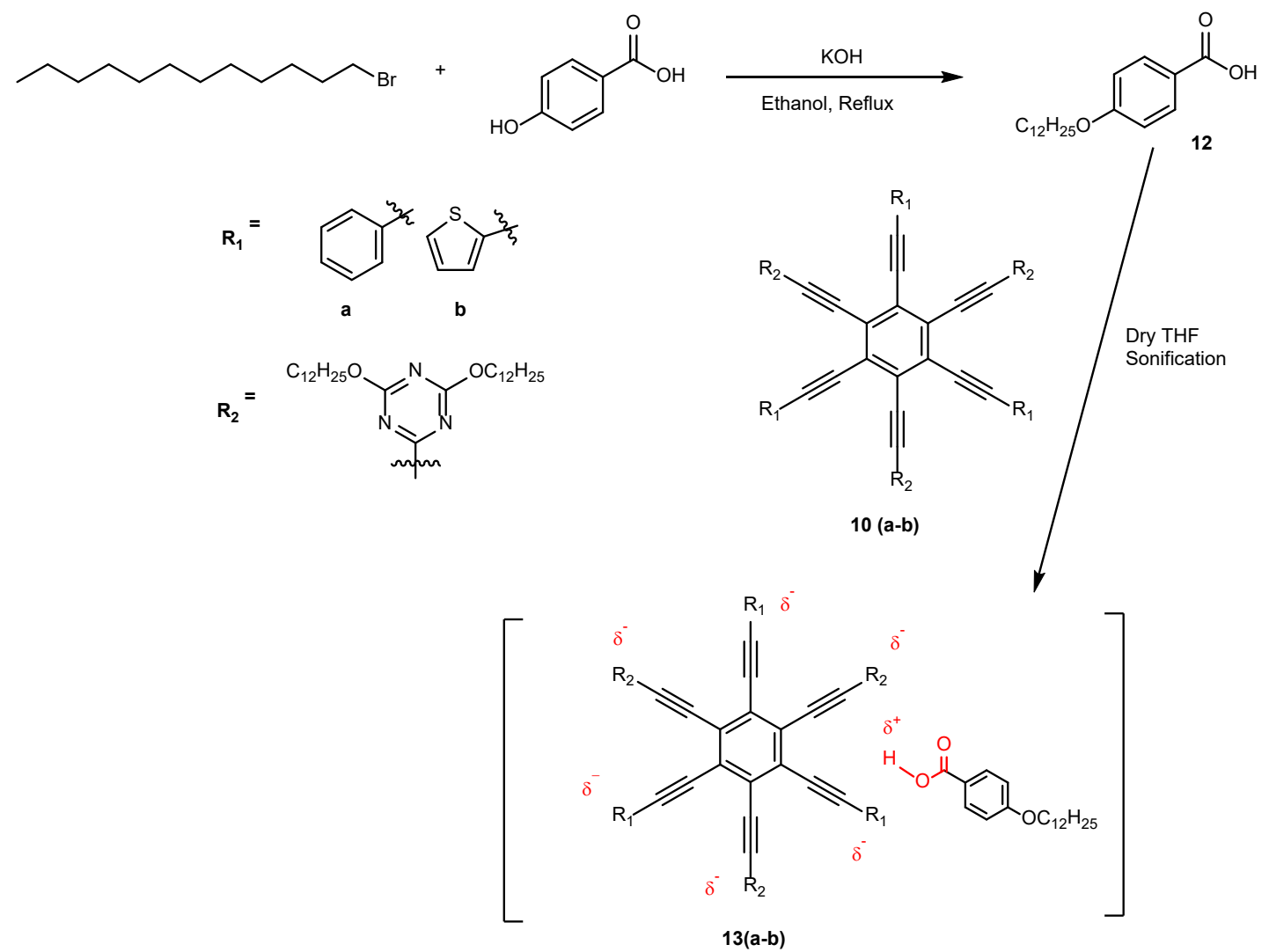

Scheme 5. Synthesis procedure of organic salt $\mathbf{1 3}(\mathbf{a}-\mathbf{b})$ 
by spectroscopic analysis and investigated by differential scanning calorimetry (DSC).

The compounds (10a, 10b) were obtained in two routes (Scheme 3, Scheme 4). In comparison, the yield of product in the second route was higher than the first route, which may occur due to the chloride that has more reactivity to couple with aromatic (ethynylbenzene, 2ethynylthiophene) than to couple with 2,4-bis(dodecyloxy)6-((trimethylsilyl)ethynyl)-1,3,5-triazine, and the reaction to achieve the product was also shorter as well [30] (Table 1).

The formation of ionic interaction between the sixarmed $\pi$-conjugated system and the mesogenic carboxyl group was mainly studied by FTIR. The sharp peak belongs to the carboxylic (Fig. 1). Moreover, asymmetric stretching carboxylate peak at $1670 \mathrm{~cm}^{-1}$ of pure 4-DBA was shifted in both organic salt to $1680 \mathrm{~cm}^{-1}$ and $1694 \mathrm{~cm}^{-1}$, respectively, after ionic interaction. In addition, peaks at 2900 and $2800 \mathrm{~cm}^{-1}$ are belonged to hydrogen stretching.

The formation of ionic interaction between the sixarmed $\pi$-conjugated system and the mesogenic carboxyl group was also checked by NMR spectroscopy. The signals corresponding to the aromatic protons of alkoxy benzoate unit shift to $(7.95,6.8) \mathrm{ppm}$ in compound (13a) and $(7.85,6.75) \mathrm{ppm}$ in compounds $(\mathbf{1 3 b})$ comparing to pure 4-DBA signals at $(8.05,6.95) \mathrm{ppm}$ - these shifting due to an increase in electron density of the aromatic ring. Similarly, the signals of oxymethylene protons of 4-DBA in ion complex shift to higher field $3.85 \mathrm{ppm}$ in compound (13a) and $3.8 \mathrm{ppm}$ in compound (13b) as compared with the signals of pure 4-DBA at $4.05 \mathrm{ppm}$ (Fig. 2). Additionally, the oxymethylene protons and aromatic protons of both organic salts show no shifting since their electronic environment did not change.

Additionally, unambiguous support for the structures of (13a), came from the QTOF analysis. The mass spectra of the organic salt indicate the presence of $[\mathrm{M}+3(\mathrm{HCOO})]^{-3}$ at 744.496 and 744.84 , as seen in Fig. 3.

Compound 4-DBA, which has an n-dodecyloxy terminal chain, shows enantiotropic liquid crystalline properties that are in agreement with the behavior observed for analogous benzoic acids carrying an alkoxy chain with the different numbers of carbon atoms at 4position of the aromatic ring [31-33]. Upon heating, 4DBA showed three peaks corresponding to $\mathrm{Cr}-\mathrm{SmC}-$ $\mathrm{N}-$ Iso transitions. On cooling from the isotropic phase, the same behavior of reverse transitions was observed. In addition to this, a calorimetric peak corresponding to $\mathrm{Cr}-\mathrm{Cr}$ transition at $65.86^{\circ} \mathrm{C}$ was detected in the cooling DSC thermogram (34). A typical texture of the SmC mesophase observed for 4-DBA is shown in Fig. 4.

Table 1. Comparison of the percentage yield

\begin{tabular}{lllll}
\hline $\begin{array}{l}\text { Comp. } \\
\text { 10(a-b) }\end{array}$ & $\mathbf{R}_{\mathbf{1}}$ & $\mathbf{R}_{\mathbf{2}}$ & Time/h & Yield/\% \\
\hline \multirow{2}{*}{ Scheme 3 } & $9 \mathrm{a}$ & 3 & 16 & 75 \\
& $9 \mathrm{~b}$ & 3 & 16 & 76 \\
\multirow{2}{*}{ Scheme 4 } & 11 & ethynylbenzene & 12 & 85 \\
& 11 & 2-ethynylthiophene & 12 & 81 \\
\hline
\end{tabular}

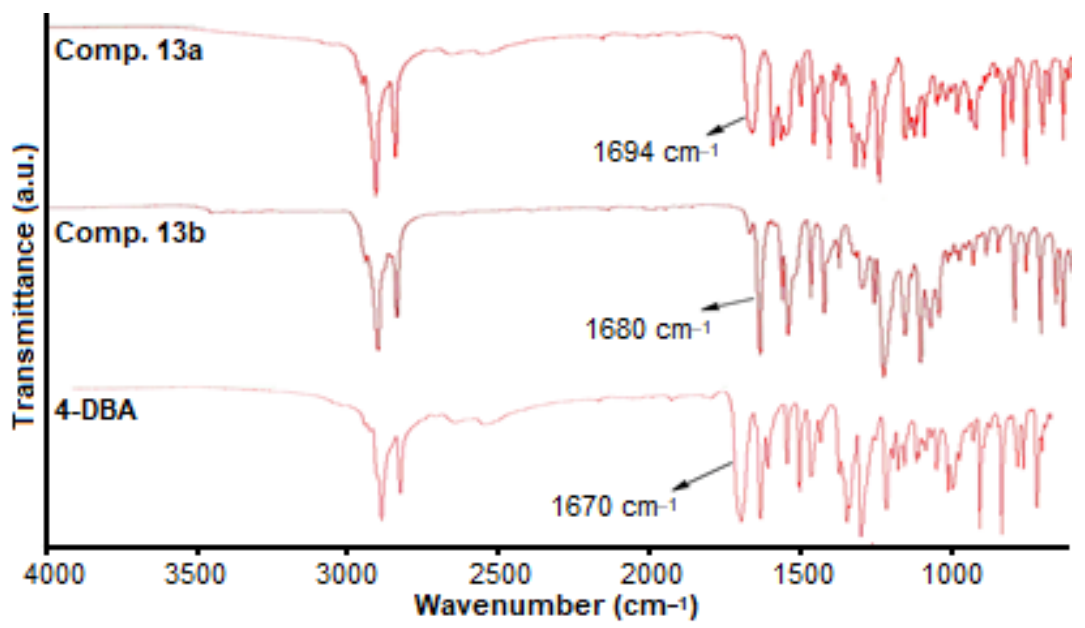

Fig 1. FT-IR spectra of organic salt (13a, 13b) and benzoic acid (4-DBA) 


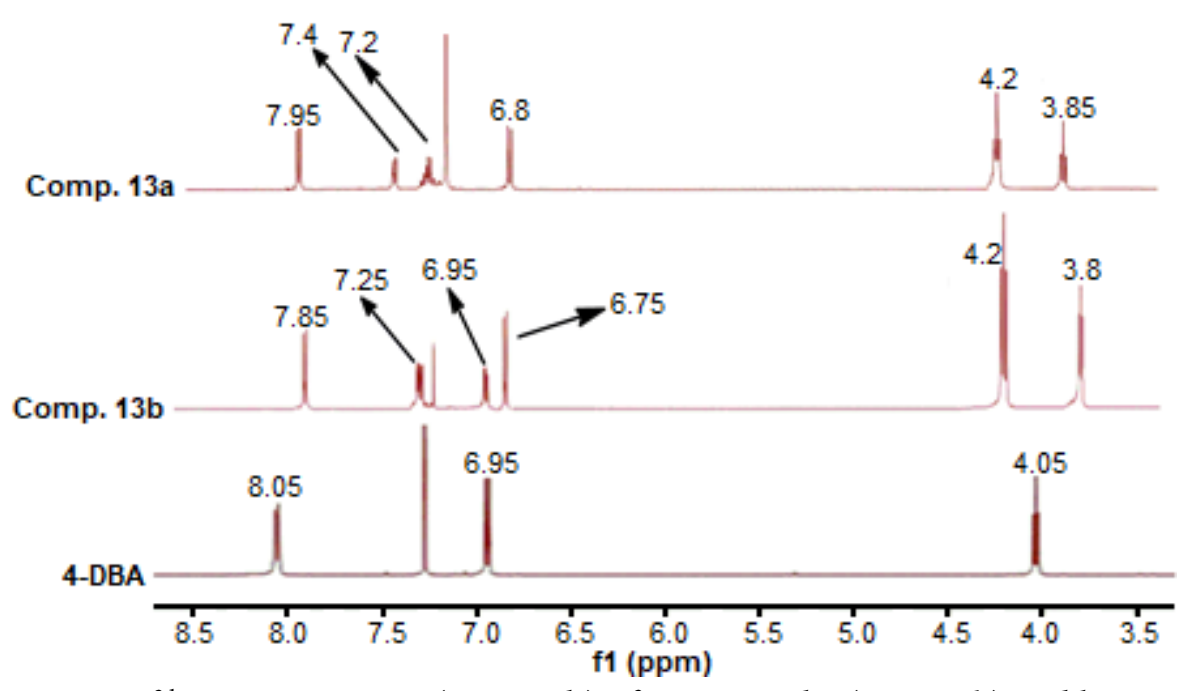

Fig 2. The comparison of ${ }^{1} \mathrm{H}-\mathrm{NMR}$ spectra (in $\mathrm{CDCl}_{3}$ ) of organic salts $(\mathbf{1 3 a}, \mathbf{1 3 b})$ and benzoic acid (4-DBA)

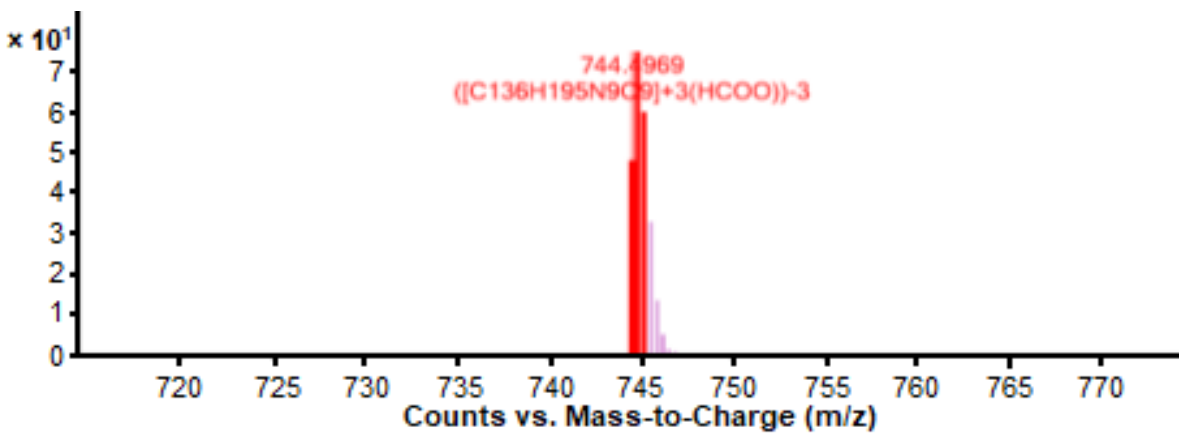

Fig 3. Q-TOF LC/MS result of organic salt (9a)
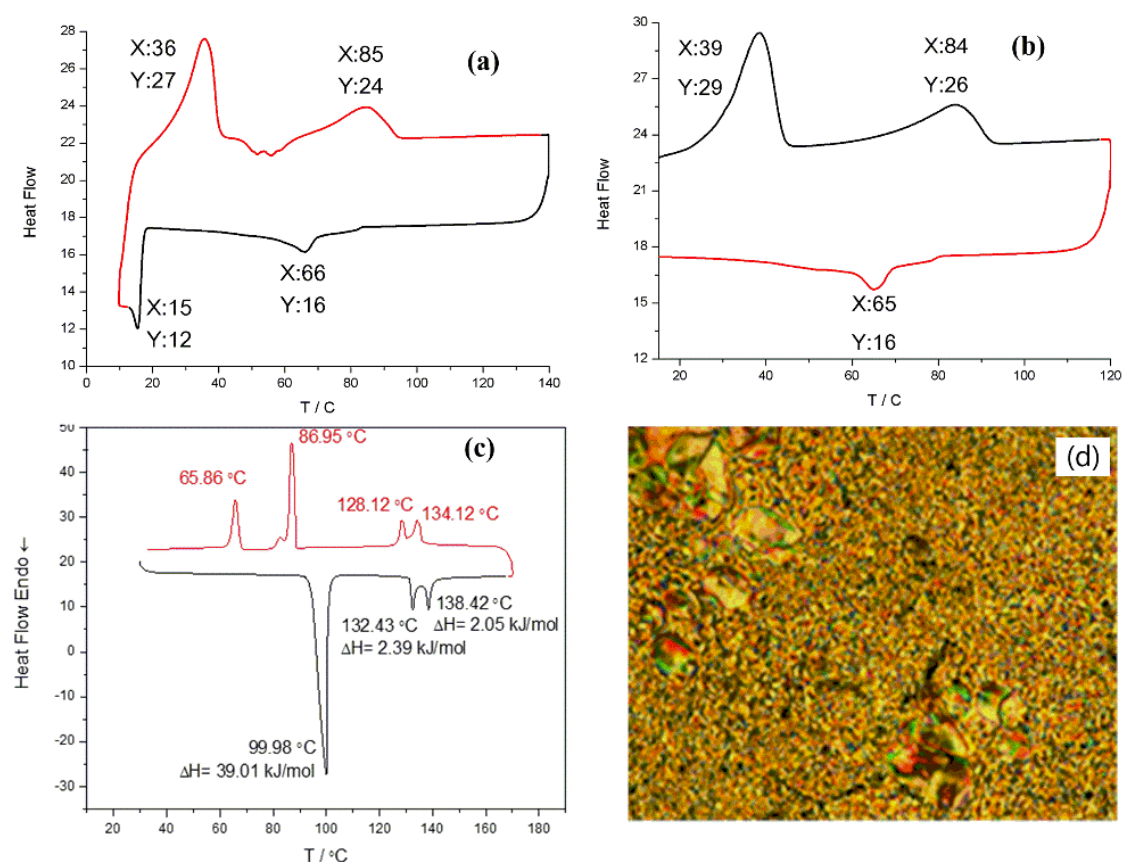

Fig 4. (a) DSC thermograms of (a) organic salt 13a, (b) organic salt 13b, (c) 4-DBA on $1^{\text {st }}$ heating and cooling $\left(10^{\circ} \mathrm{C}\right.$ $\min ^{-1}$ ), (d) A typical texture of the smectic $\mathrm{C}$ mesophase of compound 4-DBA $\mathrm{T}=118.0^{\circ} \mathrm{C}$ as observed between crossed polarizers in ordinary glass-plates on cooling 
Table 2. Mesophases and phase transition temperatures as observed on heating $(H \rightarrow)$ and cooling $(\leftarrow \mathrm{C})$ and corresponding transition enthalpies of the organic salts 13a, 13b, and 4-DBA

\begin{tabular}{|c|c|}
\hline Comp. & $\mathrm{T} /{ }^{\circ} \mathrm{C}[\Delta H \mathrm{~kJ} / \mathrm{mol}]$ \\
\hline 4-DBA ${ }^{b}$ & $\mathbf{H} \rightarrow:$ Cr 99.98 [39.01] SmC 132.43 [2.39] N 138.42 [2.05] Iso \\
\hline \multirow[t]{2}{*}{ OS (13a) } & $\mathbf{H} \rightarrow:$ Cr 12 [14.9] Col 16 [66] Iso: $\leftarrow \mathbf{C}$ \\
\hline & Cr 29.3 [38.7] Col 25.6 [83.6] Iso: $\leftarrow$ C \\
\hline \multirow[t]{2}{*}{ OS $(13 b)$} & $\mathbf{H} \rightarrow:$ Cr $15.7[65.2]$ \\
\hline & Cr 27 [36] Col 23.9 [84.9] Iso: $<\mathbf{C}$ \\
\hline \multicolumn{2}{|c|}{$\begin{array}{l}\text { aPerkin-Elmer DSC-6; enthalpy values in italics in brackets taken from the } 1^{\text {st }} \text { heating and } \\
\text { cooling scans at a rate of } 10^{\circ} \mathrm{C} \mathrm{min}^{-1} \text {; Abbreviations: } \mathrm{Cr}=\text { crystalline, } \mathrm{SmC}=\text { tilted smectic } \\
\text { phase, } \mathrm{N}=\text { nematic phase; } \mathrm{Col}=\text { columnar mesophase, Iso = isotropic liquid phase } \\
\text { [31-32] Cr } 95.1 \mathrm{SmC} 128.9 \mathrm{~N} 137.2 \text { Iso } \\
\text { [33] Cr } 92.4 \mathrm{SmC} 131.5 \mathrm{~N} 142.0 \text { Iso }\end{array}$} \\
\hline
\end{tabular}

The transition phase determined by differential scanning calorimetry (DSC), organic salt 13a, exhibits a phase transition, which is in agreement with two endotherms in the DSC heating curves. On heating, two peaks were observed at $84-27^{\circ} \mathrm{C}$. On the cooling form, the isotropic liquid, two peaks corresponding to the transition phase were observed at $66-15^{\circ} \mathrm{C}$, as shown in Fig. 4. However, for the organic salt $\mathbf{1 3 b}$, on heating, two endotherm peaks were observed at $83-38{ }^{\circ} \mathrm{C}$, whereas in the cooling cycle, one peak was observed at $65^{\circ} \mathrm{C}$, the results were summarized in (Table 2).

Both organic salts with multi-side chains, the differential scanning calorimetry revealed textures suggesting liquid crystalline states below the transitions at higher temperatures. An increase in the length of the alkoxy side chains leads to a steady decrease in the temperatures for the phase transition [35].

By the differential scanning calorimetry (DSC), two endothermic peaks were observed in the heating and cooling cycle of the compound 13a, which expected to exhibit liquid crystal phases (Fig. 4). Besides, compound $\mathbf{1 3 b}$ also showed two endothermic peaks in the heating cycle but showed one peak only in the cooling cycle, which may also exhibit a transition phase.

\section{- CONCLUSION}

A new six arms compounds based on benzene ring as a central core substituted with different aromatic compounds and three rod-like armed of 2-chloro-4,6bis(dodecyloxy)-1,3,5-triazine, using 2,4,6-trichloro- 1,3,5-triazine and 1,3,5-trichlorobenzene in the presence of palladium catalyst through the cross-coupling was efficiently synthesized. The structures were investigated by differential scanning calorimetry (DSC) and confirmed by the spectroscopic analyses $\left({ }^{13} \mathrm{C}-\mathrm{NMR},{ }^{1} \mathrm{H}-\mathrm{NMR}\right.$, and MS). The compounds were evaluated for their liquid crystal's behaviors. The results from the DSC suggested that liquid crystals behaviors of both organic salt at low temperatures are due to the ionic interaction with the complementary of 4-dodecyloxybenzoic acid, which already possessed a liquid crystal at low temperatures.

\section{- ACKNOWLEDGMENTS}

This work was supported by TUBITAK with the project no $114 \mathrm{Z} 722$.

\section{- REFERENCES}

[1] He, X.H., Han, L., Meng, F.B., Tian, M., and Zhang, B.Y., 2012, The effect of different arms on the properties of chiral branched-arm liquid crystals based on isosorbide as the chiral core, Liq. Cryst., 39 (6), 779-787.

[2] Wang, X., Bai, L., Kong, S., Song, Y., and Meng, F., 2019, Star-shaped supramolecular ionic liquid crystals based on pyridinium salts, Liq. Cryst., 46 (4), 512-522.

[3] Novotná, V., Bobrovsky, A., Shibaev, V., Pociecha, D., Kašpar, M., and Hamplová, V., 2016, Synthesis, phase behavior and photo-optical properties of bent-core methacrylate with azobenzene group and 
corresponding side-chain polymethacrylate, RSC $A d v ., 6$ (70), 65747-65755.

[4] He, W.L., Huang, Q., Yang, Z., Cao, H., Wang, D., and Yang, H., 2015, Effect of bent-shape and calamitic-shape of hydrogen-bonded mesogens on the liquid crystalline properties, Liq. Cryst., 42 (8), 1191-1200.

[5] Doganci, E., and Davarci, D., 2019, Synthesized and mesomorphic properties of cholesterol end-capped poly ( $\varepsilon$-caprolactone) polymers, J. Polym. Res., 26 (7), 165.

[6] Zhang, B.Y., Yao, D.S., Meng, F.B., and Li, Y.H., 2005, Structure and properties of novel three-armed star-shaped liquid crystals, J. Mol. Struct., 741 (1-3), 135-140.

[7] Judele, R., Laschat, S., Baro, A., and Nimtz, M., 2006, Gallic esters of 4,5-dinitrocatechol as potential building blocks for thermotropic liquid crystals, Tetrahedron, 62 (41), 9681-9687.

[8] Salisu, A.A., 2016, Synthesis and characterization of three-arm star-shaped glassy liquid crystal containing biphenyl esters, ChemSearch J., 7 (1), 37 42.

[9] Caminade, A.M., and Majoral, J.P., 2018, Engineering CNDP's of dendrimers containing phosphorous interior compositions to produce new emerging properties, J. Nanopart. Res., 20 (3), 74.

[10] Imrie, C.T., Henderson, P.A., and Yeap, G.Y., 2009, Liquid crystal oligomers: going beyond dimers, Liq. Cryst., 36 (6-7), 755-777.

[11] Iftime, M.M., Cozan, V., Airinei, A., Varganici, C., Ailiesei, G., Timpu, D., and Sava, I., 2019, Asymmetric azomethine amines with azobenzene moieties-liquid crystalline and optical properties, Liq. Cryst., 46 (10), 1584-1594.

[12] Osman, F., Yeap, G.Y., Maeta, N., Ito, M.M., Lin, C.M., and Lin, H.C., 2017, Liquid crystalline nonlinear S-shaped oligomers consisting of azobenzene and biphenylene units: Synthesis, characterisation and influence of central spacer, Liq. Cryst., 44 (1415), 2355-2365.

[13] Wang, Y.J., Sheu, H.S., and Lai, C.K., 2007, New starshaped triarylamines: Synthesis, mesomorphic behaviour, and photophysical properties, Tetrahedron, 63 (7), 1695-1705.

[14] Bao, R., Pan, M., Qiu, J.J., and Liu, C.M., 2010, Synthesis and characterization of six-arm starshaped liquid crystalline cyclotriphosphazenes, Chin. Chem. Lett., 21 (6), 682-685.

[15] Ge, L.N., Xian, S.W., Huang, Y., Min, Y., Lv, J.M., Tian, M., and Yao, D.S., 2018, Synthesis and mesomorphism of novel multi-arm liquid crystals with cholic acid as chiral center linking Schiff base moieties as mesogens, Liq. Cryst., 45 (7), 1055-1067.

[16] Barberá, J., Bardají, M., Jiménez, J., Laguna, A., Martínez, M.P., Oriol, L., Serrano, J.L., and, and Zaragozano, I., 2005, Columnar mesomorphic organizations in cyclotriphosphazenes, J. Am. Chem. Soc., 127 (25), 8994-9002.

[17] Kanibolotsky, A.L., Perepichka, I.F., and Skabara, P.J., 2010, Star-shaped $\pi$-conjugated oligomers and their applications in organic electronics and photonics, Chem. Soc. Rev., 39 (7), 2695-2728.

[18] Tuzimoto, P., Santos, D.M.P.O., Moreira, T.S., Cristiano, R., Bechtold, I.H., and Gallardo, H., 2014, Luminescent liquid crystals containing a sulphurbased heterocyclic core, Liq. Cryst., 41 (8), 10971108.

[19] Gallardo, H., and Westphal, E., 2015, Importance of organic synthesis in the development of liquid crystals, Curr. Org. Synth., 12 (6), 806-821.

[20] Sarhan, A.A.O., and Izumi, T., 2003, Design and synthesis of new functional compounds related to ferrocene bearing heterocyclic moieties: A new approach towards electron donor organic materials, J. Organomet. Chem., 675 (1-2), 1-12.

[21] Salisu, A.A., and Kogo, A.A., 2010, New Liquid crystals in the series of 1,3,5-triazine compounds containing azobenzene at the peripheral arms, Bayero J. Pure Appl. Sci., 3 (1), 54-58.

[22] Didehban, K., Namazi, H., and Entezami, A.A., 2009, Triazine-based dendrimers as liquid crystals: synthesis and characterization, Iran. Polym. J., 18 (9), 731-741.

[23] Tan, L.S., Dalton, M., and Kannan, R., 2012, Twophoton absorbing cross-linked polyurethanes 
containing delphenylamino-dialkyffluorene-1,3,5triazine units, U.S. Patent 8,318,888.

[24] Bhagavath, P., Shetty, R., and Sunil, D., 2019, 1,3,5Triazine-based liquid crystals: An up-to-date appraisal of their synthetic design and mesogenic properties, Crit. Rev. Solid State Mater. Sci., 1-32.

[25] Meier, H., Holst, H.C., and Oehlhof, A., 2003, Starshaped compounds having 1,3,5-triazine cores, Eur. J. Org. Chem., 2003 (21), 4173-4180.

[26] Lee, C.H., and Yamamoto, T., 2002, Synthesis of liquid-crystalline, highly luminescent $\pi$-conjugated 1,3,5-triazine derivatives by palladium-catalyzed cross-coupling reaction, Mol. Cryst. Liq. Cryst., 378 (1), 13-21.

[27] Beltrán, E., Serrano, J.L., Sierra, T., and Giménez, R., 2012, Functional star-shaped tris(triazolyl)triazines: Columnar liquid crystal, fluorescent, solvatofluorochromic and electrochemical properties, J. Mater. Chem., 22 (16), 7797-7805.

[28] Sundaram, S., Subhasri, P., Rajasekaran, T.R., Jayaprakasam, R., Senthil, T.S., and Vijayakumar, V.N., 2017, Observation of induced new smectic phase in supramolecular hydrogen bonded liquid crystals between mesogenic and non-mesogenic aliphatic compounds, Ferroelectrics, 510 (1), 103-120.

[29] Ambrožič, G., and Zigon, M., 2005, Hydrogen bonded liquid-crystalline polyurethane complexes with 4-dodecyloxybenzoic acid, Acta Chim. Slov., 52, 207-214.
[30] Nishihara, Y., Ikegashira, K., Hirabayashi, K., Ando, J., Mori, A., and, Hiyama, T., 2000, Coupling reactions of alkynylsilanes mediated by a $\mathrm{Cu}(\mathrm{I})$ salt: Novel syntheses of conjugate diynes and disubstituted ethynes, J. Org. Chem., 65 (6), 17801787.

[31] Kumar, C.R.S., Jha, A., and Sastry, S.S., 2010, Induced crystal $G$ phase of liquid crystalline amide through inter molecular hydrogen bonding, J. NonCryst. Solids, 356 (6-8), 334-339.

[32] Sidır, Y.G., Sidır, İ., and Demiray, F., 2017, Dipole moment and solvatochromism of benzoic acid liquid crystals: Tuning the dipole moment and molecular orbital energies by substituted Au under external electric field, J. Mol. Struct., 1137, 440-452.

[33] Stackhouse, P.J., Wilson, A., Lacey, D., and Hird, M., 2010, Synthesis and properties of novel columnar liquid crystals based on symmetrical and non-symmetrical 1,3,5-trisubstituted benzene derivatives, Liq. Cryst., 37 (9), 1191-1203.

[34] Akkurt, N., Al-Jumaili, M.H.A., Eran, B.B., Ocak, H., and Torun, L., 2019, Acetylene-bridged triazine $\pi$-conjugated structures: synthesis and liquid crystalline properties, Turk. J. Chem., 43, 1436-1444.

[35] Yang, R., Ding, L., Chen, W., Zhang, X., and Li, J., 2019, Molecular-weight dependence of phase structure and viscosity in a liquid crystalline polyester with strong $\pi-\pi$ interaction, Liq. Cryst., 46 (3), 422-429. 